\title{
SPANISH FORTIFICATIONS IN THE PHILIPPINES: INCEPTION, EVOLUTION AND CURRENT STATE OF THE FORTIFIED CITY OF CAVITE
}

\author{
J.R. JIMENEZ VERDEJO ${ }^{1}$, J.A. PULIDO-ARCAS ${ }^{1}$, C. RUBIO-BELLIDO ${ }^{2} \&$ FUNO SHUJI $^{3}$ \\ ${ }^{1}$ School of Environmental Design, University of Shiga Prefecture, Japan. \\ ${ }^{2}$ Department of Building Science, Faculty of Architecture, Construction and Design, University of Bio-Bio, Chile. \\ ${ }^{3}$ Nihon University, Japan.
}

\begin{abstract}
The fortified city of Cavite, located in Manila Bay, has played a remarkable role in the history of Spanish walled settlements in East Asia. Due to its geographical location (a peninsula protected from the open sea) and its inner harbour, whose waters allowed anchoring of large draught hulls, this small town flourished for more than 200 years as a commercial and military enclave. Unfortunately, this settlement was obliterated by air raids during World War II, and nowadays just some traces of the former city's walls and urban fabric can be seen. In this context, this research aims at clarifying the current state of this fortified city and reconstructing the historical process of its formation and transformation. Extensive fieldwork was performed in 2010 to clarify the current condition of this area; consultation of historical maps from archives and databases has provided the main chronological periods which have influenced its historical evolution. As a result, this research features a reconstruction of Cavite from 1659 , the date of its oldest graphical representation, to the present time. Also, it identifies the most representative extant structures regarding the fortification system and the urban fabric which it encloses. These outcomes provide a complete database of the scarce elements which have survived in relation to their historical appraisal, thus making a contribution to the conservation and protection of Cavite, a part of the Spanish colonial architectural heritage in the Philippines.

Keywords: fortified city, historical evolution, Philippines, Spanish colonial heritage.
\end{abstract}

\section{INTRODUCTION}

During the nearly 400 years of Spanish rule in the Philippines, the Spanish settlers founded more than 200 cities with the traditional grid typology [1], along with extensive defensive structures and also religious complexes, convents and churches, as part of colonization of the territory.

The authors have already performed extensive studies in the field of extant Spanish colonial heritage in the Philippines; their studies have focused on the historical evolution of fortified cities such as Intramuros in Manila [2]; the evolution of the Urban grid of the city of Cebu [3]; the historical evolution and spread of the Spanish grid city around America and Asia [4]; the historical evolution of the Parian district in Manila, the first Chinatown in the world [5]; the study of Daniel Burnham's master plan for the city of Manila [6]; the urban space of colonial Manila [7, 8]; the structure of the Spanish settlements in the island of Cebu [9, 10]; studies of house types in the Philippines [11] and the expansion of the Spanish colonial city planning across the Philippines [12-14].

Amongst these studies, references to the city of Cavite are scarce. Some studies have been conducted regarding the social structure of the city at present time [15] or in the past [16], because of its historical importance as a trading port in Manila. However, the authors [17]

\footnotetext{
This paper is part of the Proceedings of the 3rd International Conference on Defence Sites: Heritage and Future (Defence Heritage 2016)

CONFERENCES www.witconferences.com
} 
have proven the hypothesis that a strategically located and well-populated port city, which is suitable for easy trade by virtue of its harbour and for defensive purposes results in the development of a rich urban fabric as a result of the commerce, together with a defensive system which ensures the proper defence of commercial and military interests.

This specific combination brought attention to this small enclave, which is located on the southern fringes of the vast conurbation of Mega Manila, being part of a larger extension with the legal denomination of 'Cavite city'. For this reason, a distinction has to be made between this city and what will be called hereinafter 'fortified city of Cavite', which refers to the historical quarter enclosed by the walls. In this way, the inception, evolution and current state of this ensemble should be understood as a whole, embracing the urban tissue together with the fortification system itself, as no clear distinction can be made between the two elements.

\section{OBJECTIVES AND METHODOLOGY}

The main objective of the research is to clarify the process of inception and evolution of fortified city of Cavite through history, and to clarify the current state of the whole ensemble. In order to accomplish these objectives, the following issues have to be clarified:

- Identify the main historical events which have shaped the evolution of the city, in order to establish the breakpoints for the study.

- Identify the main elements which have prevailed, changed or disappeared through the historical evolution and classify them into defensive elements (walls, watchtowers, bastions), urban landmarks (streets, squares, urban voids) and architectural landmarks (civil buildings, churches, prominent houses).

- Identify amongst the former the elements which still prevail in the current fortified city of Cavite.

- Establish relations of causality between the historical events and the formation and evolution of all the elements identified in the study.

The methodology is based mainly on a comparative study between the successive phases of this city through history, and a final comparison with the extant state. The steps which have been followed are as follows:

1. Compilation of documents regarding the historical evolution of fortified city of Cavite. The following databases have been consulted: military archives; Geographic Service of the Spanish Army (Servicio Histórico Militar (SHM), Servicio Geografico del ejercito) $[18,19]$, which provides a set of historical maps together with a complete transcription of their original legends; PARES [20], Spanish electronic database of archives (Portal de archivos españoles). Moreover, as the Philippines was under American administration from 1898 to 1946, databases from the United States were also consulted. The electronic portal of the US Library of Congress [21], US National Archives [22], private databases of US soldiers, available online [23], personal photographic databases of researchers, available online [24], have also material which complements ones available from the former resources.

2. All these materials were organized into three main categories. First, graphical documents, making a distinction between general plans, including maps of the urban grid and the fortified elements, and plans regarding specific representative buildings and fortifications. Secondly, complementary descriptions of the former group, which include map legends, transcriptions and clarifications. Thirdly, photographs, which have been related 
with the elements to which they refer. Finally, those additional materials which were used to compose the context of the fortified city of Cavite.

3. From points (1) and (2), after statistical treatment, data mining and historical analyses were undertaken to clarify two points. First, the main landmarks, regarding both the fortified system and the urban grid which have remained through time, either altered or unaltered. Secondly, the time periods which can be established to understand the historical evolution of this city.

4. Fieldwork was conducted in the area of fortified city of Cavite in two campaigns. The first one was conducted in September 2009 and was aimed at a complete assessment of the extant urban grid; the second one was conducted in August 2015 and reassessed specific elements previously identified in 2009. Plans have been produced regarding the results of this phase of the work.

5. Finally, a comparative study between each historical milestone defined in point (3) and the current state defined in point (4) was done in order to clarify the final conclusions of the study.

\section{HISTORICAL FORMATION OF FORTIFIED CITY OF CAVITE}

1659 - The first recorded map of Cavite dates back from 1659. In 1571 the Spanish established a settlement in Manila, as well as in Cavite, which was conceived from the beginning as the port of Manila Bay. This port, the nearby seacoast settlements and Manila were declared royal encomienda on 16 January 1571. This medieval form of social organization was aimed at a rapid evangelization. The missionaries' 'encomenderos' had the obligation to bring the natives near the religious compounds (parishes, churches and convents). From Fig. 1 and the corresponding map (Fig. 2), it is remarkable that, between 1571 and 1659, an urban structure was laid out and organized around religious buildings (2, 3, 4, 5 and 6). The Augustinians, the Franciscans (1580) and the Jesuits (1624) were the religious orders who took the responsibility of extending the Catholic faith to the Philippines. The only prominent civil building is the Casa Real (1). The urban tissue was organized following the typical Spanish grid pattern, but with irregular block dimensions. The fortification system consisted at this point of some basic elements. Elements A-E comprised a wall, two towers and a moat, together with Puerto Vaga, the main access to the city. Fort San Felipe (F) was the main military bastion, which was located in the central portion of the peninsula. The Cube of Santa Catalina Martir (G) was a viewpoint in the eastern extreme of Cavite, in order to control maritime traffic. Auxiliary military installations, such as ironworks $(\mathrm{H})$, can also be identified at this point.



Figure 1: MP-Filipinas 143, Cavite, 1659. 


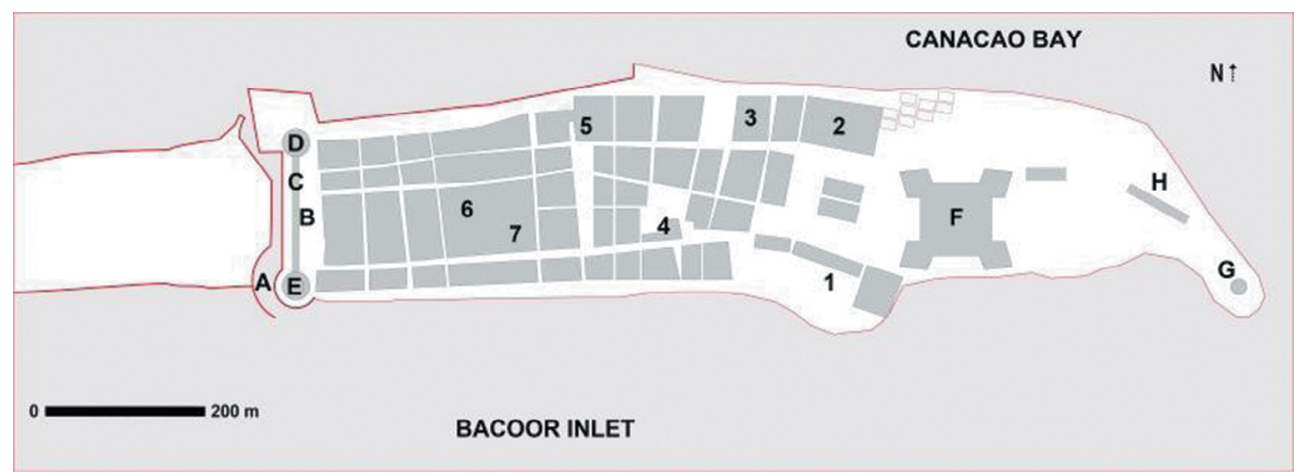

Figure 2: Cavite, 1659.

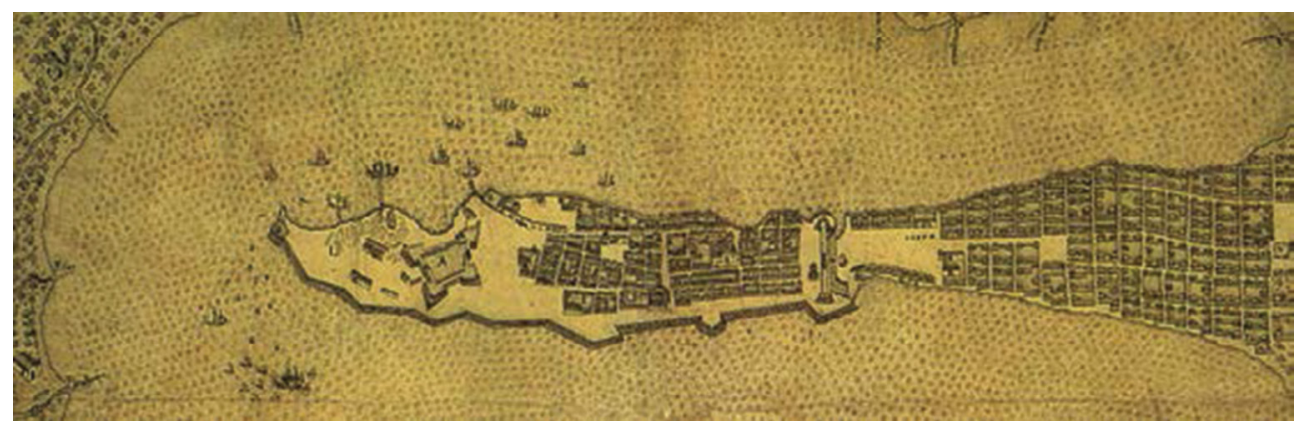

Figure 3: SHM 1, Cavite, 1730.



Figure 4: Cavite, 1730.

1730 - No remarkable differences can be appreciated from the map of 1659 (Figs. 3 and 4). The urban grid maintains a similar pattern. All the representative buildings remain the same, with the exception of the Franciscan Convent, which had disappeared at this point. The fortified system shows an expansion on the north side (I, J, K, L and M), with the objective of protecting the city against the waves of the open sea. Fort San Felipe remains the same (F) and the Cube of Santa Catalina (F) is reinforced as a strategically important viewpoint with new embankments. In the eastern part of the peninsula, new military installations are 


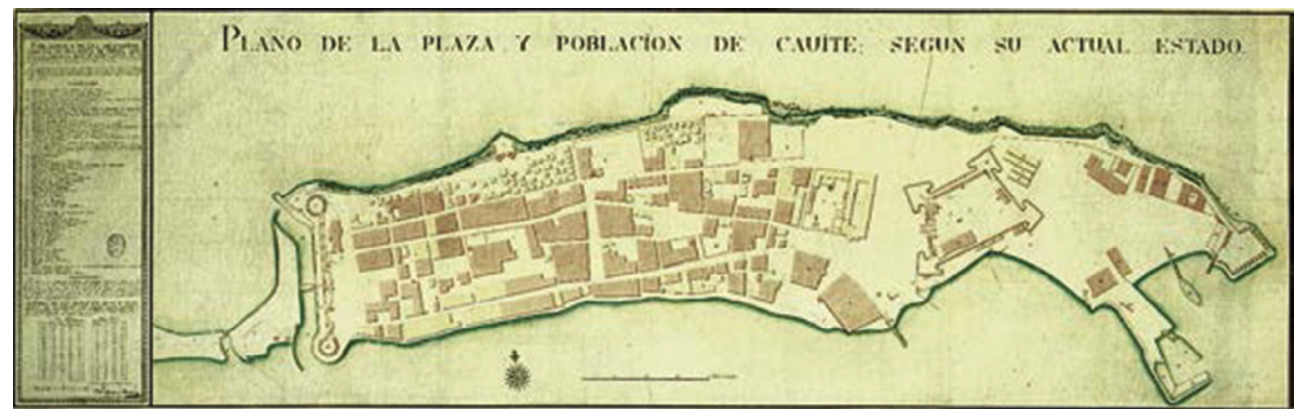

Figure 5: SHM 42, Cavite, 1815.

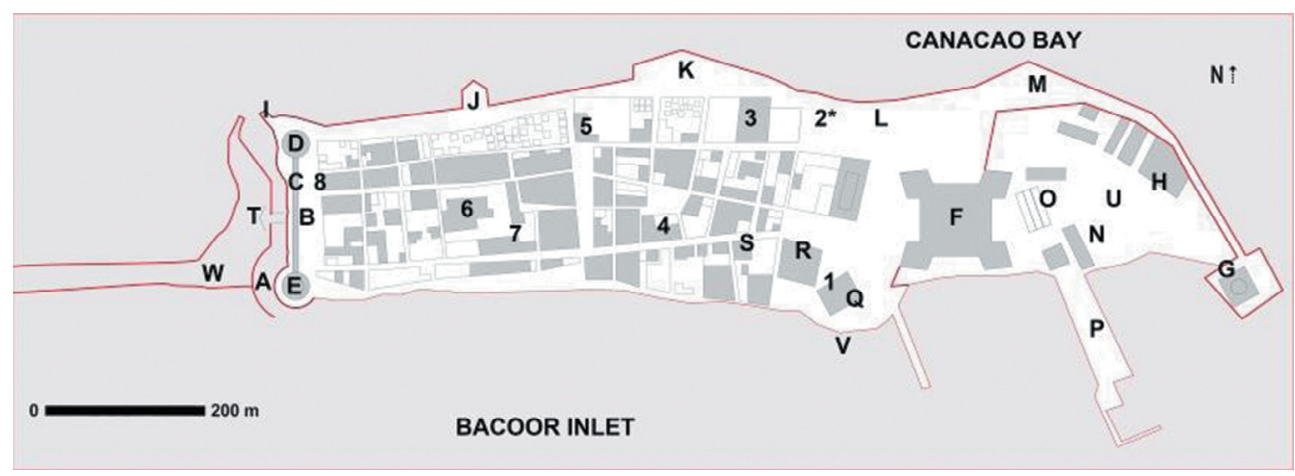

Figure 6: Cavite, 1815.

added: The Herrerias $(\mathrm{M})$, an extension of the ironworks; the rivera $(\mathrm{N})$, a shipyard for the maintenance of vessels; the Casa del Apunton $(\mathrm{O})$; the Puente para carenar $(\mathrm{P})$, a dock for repairing the hull of the vessels; the punta de rivera $(\mathrm{Q})$, which is supposedly an extension of the former Casa Real; Galeras de forzados (R), a place where convicted prisoners were imprisoned with hard labour; and warehouses $(\mathrm{S})$. With respect to the entrance from the mainland, the revellin de entrada $(\mathrm{T})$ was added as a new defensive element for the main gate of the fortified city.

1815 - This document depicted in Fig. 5 is very valuable, as it shows a detailed map of the city. Remarkable changes can be appreciated both in the urban grid and in the fortification system (Fig. 6). Regarding Fig. 5, the used and vacant lots in each block can be approximately assessed, revealing more details about the urban structure of ancient Cavite. Two new representative religious buildings can be appreciated, St Juan de Dios Convent (7) and La Soledad Chapel (8). With respect to the fortification system, relevant changes can be appreciated. First, the north flank (I, J, K, L and M) was, according to the legend of the historical map, in a state of ruin. The walls were built either with masonry or with a mixture of earth and wood sticks (tierras y faginas), constituting a weak defence against the sea waves, which explains the perilous state of these walls. Former Cube of Santa Catalina is denoted in this map as Guadalupe battery $(\mathrm{G})$, which was updated with a base of masonry; despite this improvement, legend describes it as a ruin, due to its exposition to the sea. For the first time, a formal delimitation for the zone in the eastern part of the peninsula, enclosing the military 


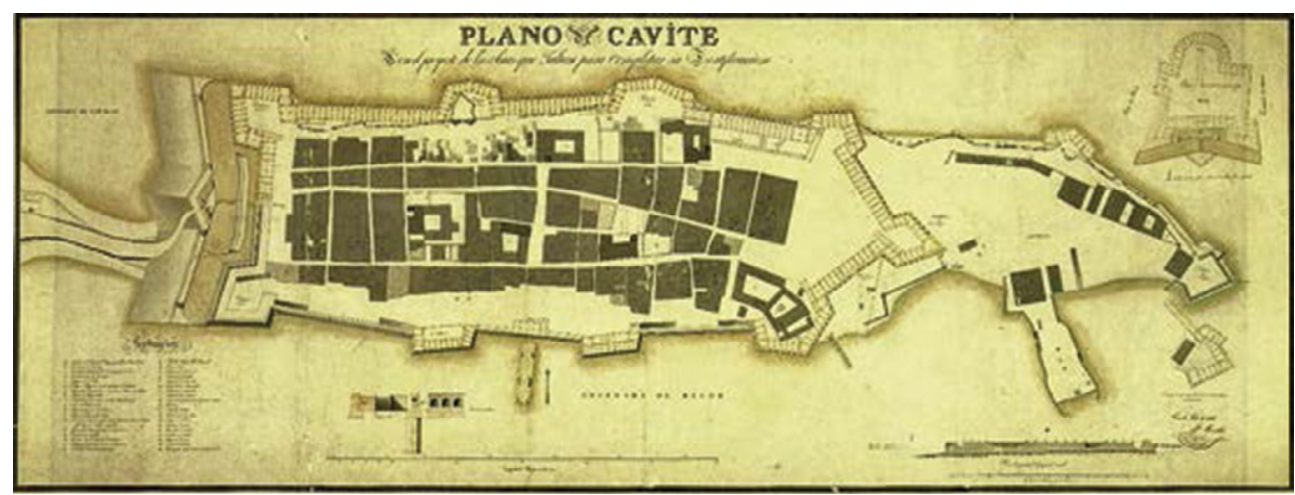

Figure 7: SHM 78, Cavite, 1841.

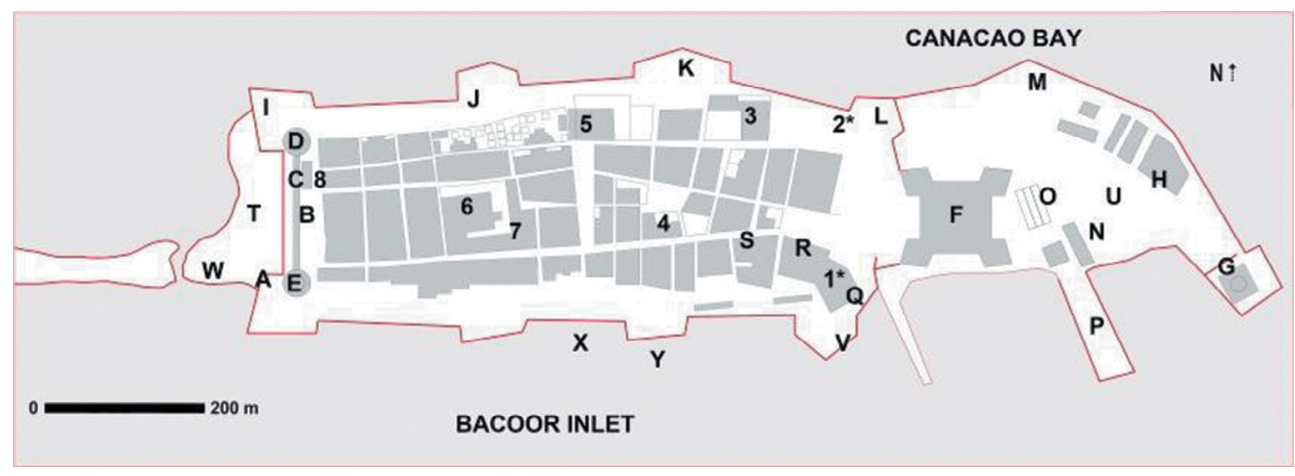

Figure 8: Cavite, 1841.

compound, can be seen. New premises were added to this area, such as the royal arsenal (U), used as a warehouse to store weapons. The dock for repairing vessels $(\mathrm{P})$ was also expanded. Batteries were also installed facing the Bacoor inlet $(\mathrm{V})$ and for the defence of the mainland gate $(\mathrm{W})$.

1841 - Fig. 7 shows a map at a later stage of the process which was initiated in 1815, with the completion of the fortification system around the urban grid and the complete isolation of the military area in the eastern part. The fortification system (Fig. 8) was completed with the inner defence line $(\mathrm{X}, \mathrm{Y})$ facing Bacoor inlet. The direct access to Guadalupe bastion (G) is interrupted in order to isolate the military area, with the expansion of the San Telmo Bastion (L).

1880 - No new elements can be appreciated in this stage (Fig. 9). The only remarkable structures which can be outlined (Fig. 10) are the expansion and partial completion of the refurbishment of San Miguel Bastion (K), San Telmo Bastion (L) and Herrerias Bastion (M). This can be considered as the final state of fortified city of Cavite, with a fortified urban area, surrounded by walls along its perimeter, a defence line against ground attacks in the western flank and an isolated military compound in the eastern area, with the prominent element of Fort San Felipe (F) and a buffer zone to protect it from the civil settlement. The city would pervade in this condition, despite its suffering some damages in the American-Spanish war in 1898. 


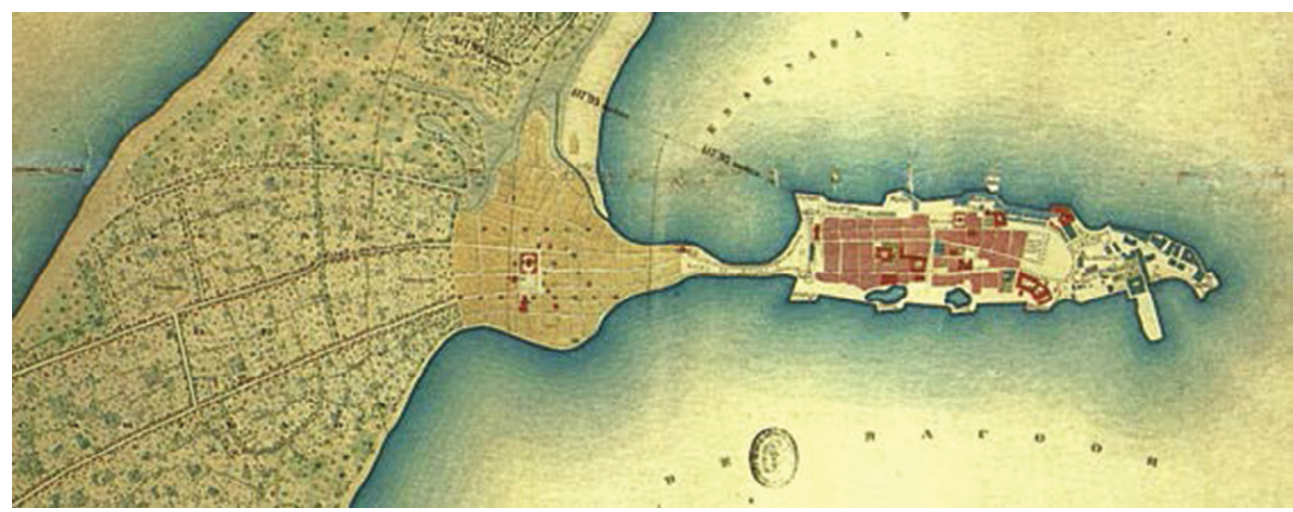

Figure 9: SHM 117, Cavite, 1880.

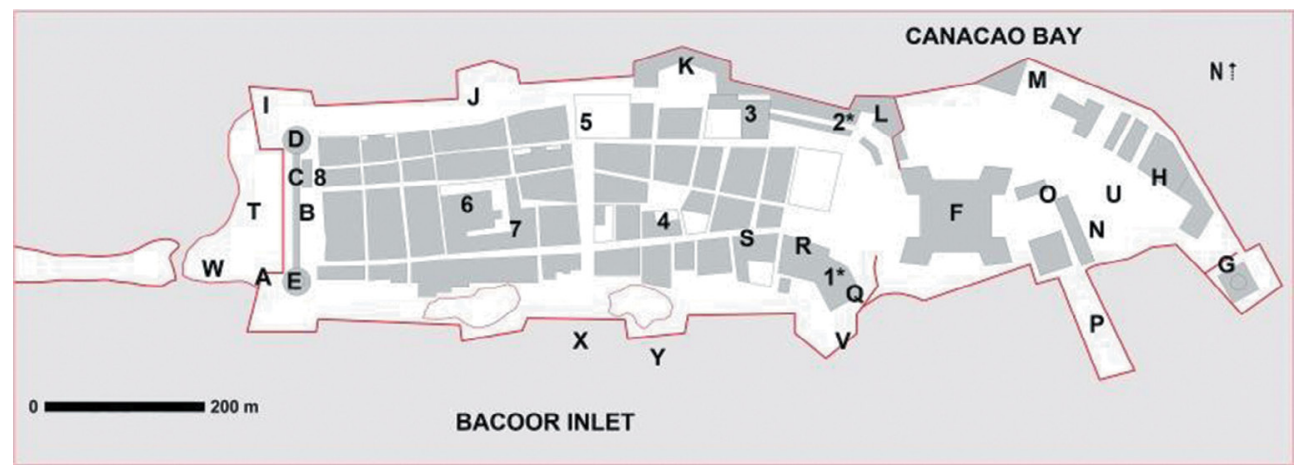

Figure 10: Cavite, 1880.

1941-1945 - In this stage, due to the exceptional events which took place not only in Cavite, but in the Philippines and the world as well, the analysis was done with aerial photographs of the previous and later stages of fortified city of Cavite. Manila suffered heavy bombing during World War II, first from the Japanese and then from the US Army Air Force. Cavite was a strategic point for controlling Manila Bay, and for this reason, it was also a primary military target. Two aerial images, from 1941 (Fig. 11) and 1945 (Fig. 12), show the devastation which this city suffered. The heavy bombing destroyed all buildings, with the exception of some elements, and the fortification system is only visible in its basic traces.

List of fortification elements

(A) Moat, (B) Puerto Vaga, (C) Murallas de Tierra, (D) North tower, (E) South tower, (F) Fort San Felipe, (G) Cube of St Catalina the Martyr $\rightarrow$ Guadalupe battery, (H) Ironworks, (I) La Soledad battery, (J) St Juan Bastion, (K) San Miguel Bastion, (L) San Telmo Bastion, (M) Herrerias (ironworks) Bastion, (N) Rivera, (O) Casa del Apunton, (P) Puente para carenar, (Q) Punta de Rivera, (R) Galeras de forzados, (S) Warehouses, (T) Revellin de entrada, (U) Royal arsenal, (V) Bateria de almacenes, (W) San Ignacio batteries, (X) Inner sea defence line, (Y) Outline for a docking line. 


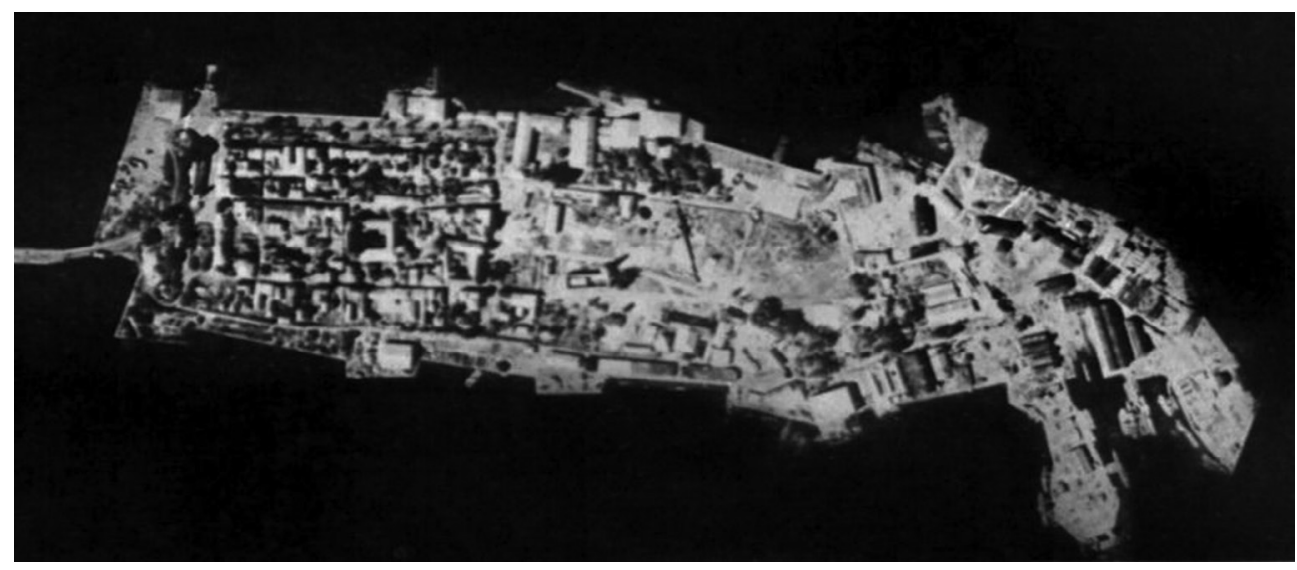

Figure 11: Cavite, 1941.

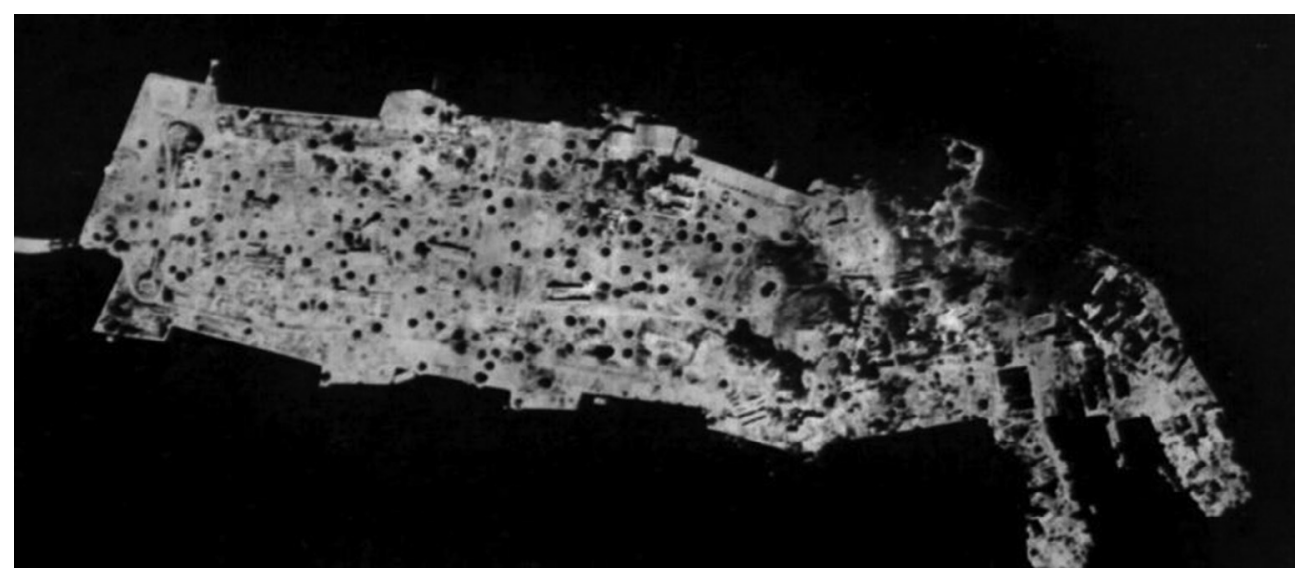

Figure 12: Cavite, 1945.

\section{List of urban landmarks}

(1) Casa Real, (2) St Francisco Convent, (3) St Domingo Convent, (4) Iglesia Mayor, (5) Society of Jesus Church (from 1801 school), (6) St Nicolas Convent, (7) St Juan de Dios Convent, (8) La Soledad Chapel, (9) St Juan de Dios Hospital.

\section{FIELDWORK}

2015 - Fieldwork was conducted in 2011 and 2015 in order to assess the current state of the elements which were previously identified in the analysis of historical maps (Fig. 13). In general, due to the intense destruction caused during the war, practically no elements remain. The former embankment defined by the north flank of the fortification (Fig. 13: I, J and K) still keeps its original shape; the same applies to the fortification facing Bacoor inlet (Fig. 13: $\mathrm{X}$ and $\mathrm{Y}$ ). In the fieldwork the authors identified remaining stone foundations of the old fortification in the seashore on the south tower of Puerto Vaga (Fig. 13: E). These foundations are around the main gate, Puerto Vaga (Fig. 13: A, B, C, D and E), which is now the main 


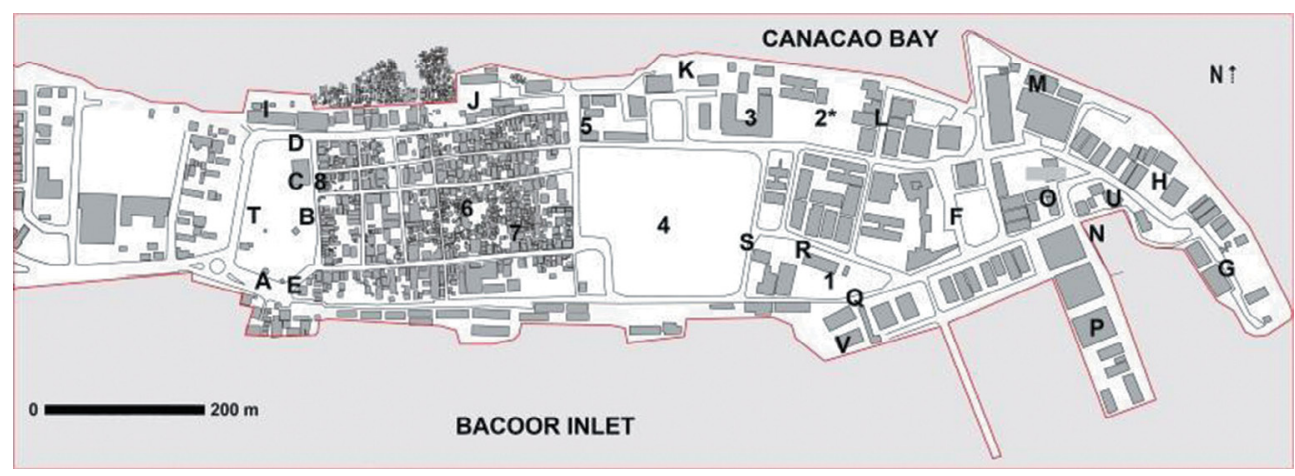

Figure 13: Cavite, 2015.

square of Cavite city, and the city hall today stands (Fig. 13: I) in the original place of La Soledad battery.

The current urban structure in the central strip of the peninsula follows the basic grid of the old city, although all former buildings have been destroyed. No religious complex or civil building from the Spanish period stands today in Cavite. The only remaining structure which could be identified by the authors was the tower of ancient San Nicolas Convent (Fig. 13: 6), which nowadays is hidden into the houses and is in a perilous state. The old military compound from the Spanish period has expanded, occupying the area around Iglesia Mayor (Fig. 13: 4). Nowadays no access is granted to civilians beyond this point, so the military area had to be assessed by aerial photographs. Inside this complex, the only remaining defensive structure identified is the west flank of Fort San Felipe (Fig. 13: F), which, according to historical records, was partially demolished by the Americans after the 1898 war for their convenience, and has been used as a military installation since then. The western flank of the Peninsula is used as a military port, but the successive construction of embankments, docks and warehouses has heavily modified the coastline, so that no traces of the original compound can be recognized.

\section{CONCLUSIONS}

The historical process of inception, formation and transformation of the fortified city of Cavite has been clarified. The historical evolution of the fortified system can be summed up in the following stages. In the first stage, in the 17th century, a basic defensive system against ground attacks, together with the fortified bastion of Fort San Felipe and the Cube of Santa Catalina Martir, was accomplished. In a later stage, a defensive system which would enclose the urban fabric was outlined, which was developed progressively during the 18th and 19th centuries. This defensive system was completed in 1841, and successively enhanced until at least 1880. An exhaustive list of defensive elements and relevant civil buildings of the old fortified city of Cavite has been elaborated, making it possible to identify the main milestones of this ensemble.

The remaining elements of both civil and defensive structures have been identified; they are scarce and also in a poor state of conservation. Based on a global assessment by the authors, it could be stated, after the analysis of the historical documents and the result of the fieldwork, that the fortified city of Cavite was a splendorous ensemble embracing both a rich urban structure and a complex and extensive defensive system, being comparable in 
heritage value to the nearby Intramuros district in Manila. Its peculiar characteristics allow for comparison with other cases also studied by the authors, like the fortified city of Cadiz in Southern Spain. A peninsula with a prominent location for military defence and trade within the inlet of a bay produces, in turn, this kind of fortified urban nucleus, combining both military and trading functions.

As the historical records about the fortified city of Cavite are scarce and difficult to access, it is advisable to conduct further research on this topic, especially in order to identify more exact dates regarding the design and construction of each element of the defence system, as well as the most prominent civil buildings.

\section{REFERENCES}

[1] Chias, P. \& Abad, T., Colonial urban planning and land structures in the Philippines. Journal of Asian Architecture and Building Engineering, 11(1), p. 16, May 2012. DOI: 10.3130/jaabe.11.9

[2] Jimenez Verdejo, J.R., Cabeza-Lainez, J.M., Pulido-Arcas, J.A. \& Rubio-Bellido, C., Spanish fortifications in Asia: A case study of Intramuros district in Manila - Current situation and future prospects. WIT Transactions on the Built Environment, 143, pp. 387-398, 2014, ISSN 1743-3509. DOI: 10.2495/DSHF140331

[3] Jimenez Verdejo, J.R. \& Shuji Funo, Considerations on the urban formation process and formation of urban Core of Cebu (Philippines). Journal of Architecture and Planning (Transactions of AIJ), 76(668), pp. 1867-1874, October 2011. (in Japanese) DOI: $10.3130 /$ aija.76.1867

[4] Jimenez Verdejo, J.R. \& Shuji Funo, The Grid City: Spanish Colonial Cities. Origin, Formation and Transformation, Kyoto University Press, Kyoto, March 2013, ISBN-10: 4876982686. (in Japanese)

[5] Jimenez Verdejo, J.R. \& Shuji Funo, Consideration on formation of Parian in Manila. Journal of Architecture and Planning (Transactions of AIJ), F1, p. 417, September 2012. (in Japanese)

[6] Jimenez Verdejo, J.R. \& Shuji Funo, A study on space formation of Philippines. Part 04. Burham's plan of Manila. Journal of Architecture and Planning (Transactions of AIJ), F1, p. 893, September 2012. (in Japanese)

[7] Jimenez Verdejo, J.R., Shuji Funo, Hizawara Hi \& Umetani Keizo, Considerations on the urban formation of Binondo and San Nicolas District in the City of Manila. Proceedings of the 9th International Symposium on Architectural Interchanges in Asia (ISAIA) (20121122), Gwang-Ju, Korea, 2012.

[8] Jimenez Verdejo, J.R., Shuji Funo, Hizawara Hi \& Umetani Keizo, A study on space formation of Pilipino Part 2: urban formation and institution distribution, August 2008. Proceedings of the Annual Meeting of the Japanese Institute of Architects 2011, Tokyo. (in Japanese)

[9] Jimenez Verdejo, J.R., Shuji Funo \& Yamaguchi Kenta, A study on the style of church architecture churches in Cebu, Philippines, August 2011. Proceedings of the Annual Meeting of the Japanese Institute of Architects 2011, Tokyo. (in Japanese)

[10] Jimenez Verdejo, J.R., Shuji Funo \& Yamaguchi Kenta, Considerations on the urban formation process of Cebu (Philippines), August 2011. Proceedings of the Annual Meeting of the Japanese Institute of Architects 2011, Tokyo. (in Japanese)

[11] Jimenez Verdejo, J.R., Study on typology and transformation of Bahay na Bato Housing in Vigan, Philippines. Proceedings of the 8th International Symposium on Architectural Interchanges in Asia (ISAIA), Kitakyushu, September 2010. 
[12] Jimenez Verdejo, J.R., Shuji Funo, Yamada Kiyoshi, Yamaguchi Kenta \& Meshida Satoshi, Study on formation and transformation of Spanish colonial city in Philippines, September 2010. Proceedings of the Annual Meeting of the Japanese Institute of Architects 2010, Tokyo. (in Japanese)

[13] Jimenez Verdejo, J.R., Shuji Funo, Yamada Kiyoshi, Yamaguchi Kenta \& Meshida Satoshi, Study on formation and transformation of Spanish colonial city in Philippines (Part 02, Vigan city), September 2010. Proceedings of the Annual Meeting of the Japanese Institute of Architects 2010, Tokyo. (in Japanese)

[14] Jimenez Verdejo, J.R., Shuji Funo, Yamada Kiyoshi, Yamaguchi Kenta \& Meshida Satoshi, Study on formation and transformation of Spanish colonial city in Philippines (Part 3. Bahay na bato housing types in Vigan), September 2010. Proceedings of the Annual Meeting of the Japanese Institute of Architects 2010, Tokyo. (in Japanese)

[15] Kelly, P.F., From global production networks to global reproduction networks: Households, migration, and regional development in Cavite. Regional Studies, 43, pp. 449461, 2009, ISSN 1360-0591. DOI: 10.1080/00343400902777075

[16] Borromeo-Bühler, S., The inquilinos of Cavite and Filipino class structure in the late 19th century. Asian Studies, 21, pp. 41-58, 1983.

[17] Jimenez Verdejo, J.R., Pulido Arcas, J.A. \& Shuji Funo, Consideration on urban and block formation in the old quarter of Cadiz. Journal of Architecture and Planning (Transactions of AIJ), 80(713), pp. 1557-1564, July 2015.

[18] Cartografia y relaciones históricas de Ultramar. Tomo X. Filipinas, Volumen de cartografia, Ministerio de Defensa: Madrid, ISBN: 84-7823-508-6, 1996. (in Spanish)

[19] Cartografia y relaciones históricas de Ultramar. Tomo X. Filipinas, Volumen descriptivo, Ministerio de Defensa: Madrid, ISBN: 84-7823-507-8, 1996. (in Spanish)

[20] PARES, available at http://pares.mcu.es/.

[21] US Library of Congress, available at http://www.loc.gov/.

[22] US National Archives, available at http://www.archives.gov/.

[23] Clarks Veterans Cemetery Restoration Association, available at http://www.cvcra.org/.

[24] Flickr account of John Tewell, available at https://www.flickr.com/people/johntewell/. 